\title{
FORECASTING BANKRUPTCY RISK IN THE CONTEXTS OF CREDIT RISK MANAGEMENT - A CASE STUDY ON WHOLESALE FOOD INDUSTRY IN POLAND
}

\author{
RAFAL BALINA
}

\begin{abstract}
:
The aim of the article was to identify the key factors influencing the increase in the risk of bankruptcy of companies from wholesale food industry in Poland. In addition, the research aimed to identifying the most effective method of forecasting the risk of bankruptcy of enterprises in the examined industry in the context of risk management in banks. The research showed that three key indicators determining the financial situation of the enterprise were the key for the analyzed industry: ratio of own equity and the revenue from sale; difference between the quick liquidity indicator for the industry and for the company and dynamics of company's short term liabilities. These variables point to the areas of activity of companies from wholesale food industry, to which banks should pay special attention during the credit risk assessment process.
\end{abstract}

\section{Keywords:}

bancruptcy, credit risk, food industry, neutral network, linear discriminat, logistic regresion

JEL Classification: G33, G21, G32

\section{Authors:}

RAFAL BALINA, Warsaw University of Life Sciences - SGGW, Poland, Email: rafal_balina@sggw.pl

\section{Citation:}

RAFAL BALINA (2018). Forecasting Bankruptcy Risk in The contexts of Credit Risk Management - A Case Study on Wholesale Food Industry in Poland. International Journal of Economic Sciences, Vol. VII(1), pp. 1-15., 10.20472/ES.2018.7.1.001 


\section{Introduction}

The food industry is one of the most important and fastest growing branches of the Polish economy. It is a branch of a relatively high macroeconomic impact to the polish economy, which plays an important role in the creation of gross domestic product, in international exchange, in satisfying domestic demand or in the labor market. In addition, Poland's functioning within the global economy has created new opportunities for the food industry in the form of foreign markets, but also opened up the market to international competition. The opening up of the food market in Poland has resulted in major changes resulting, inter alia, from the adjustment process to global requirements and the aftermath of the global economic crisis. Although it did not cause a dramatic change in the structure of the food industry, it contributed to reducing the number of companies operating in the food industry by more than 3,500 in 2010-2015. At the same time most bankruptcies were recorded in the wholesale of food. This was very common with their bankruptcies, which in many cases was a significant problem for other companies and financial institutions that cooperated with them. It is therefore an important issue to assess the risk of bankruptcy of companies in this industry so that the potential bankruptcy can be identified quickly and appropriately, especially in banks where lending to companies threatened with bankruptcy poses a significant risk.

The purpose of this article was to identify key financial and organizational factors that would allow early identification of the symptoms of the deteriorating financial situation of companies handling the wholesale of food, and to develop an effective tool that would effectively identify the risks of bankruptcy of companies in the industry. In addition, the results of the research enabled us to identify the most effective method for assessing the threat of bankruptcy of enterprises in the examined industry.

Under the current economic situation, a company is considered bankrupt when its market value cannot cover its debt even though it continues to function. In other words, a corporation may be considered insolvent - is in bad economic-financial condition having relatively good production results; the condition where a company is bankrupt is when it cannot independently manage its statutory obligations without outside help. This outside help can take many forms: partial cancelation of debt, delayed payment, negotiating an agreement with creditors or re-scheduling payment, additional financing, incorporation into another company or the issuance of government guarantees. In many cases a financial crisis - an unplanned process, an unplanned chain reaction at a given time which endangers the very existence of the company - precedes bankruptcy. This should be construed as the result of unplanned random events or improper decisions which will weigh on the firm's functioning in the future. It is to be understood as the culmination and permanent loss of liquidity caused by the inability to hold costs below receipts. Corporate bankruptcy is an integral part of market economies where they relieve the market of enterprises which are not economically justifiable (Mączyńska \& Zawadzki, 
2006); bankruptcies are one of the indicators which enable competition. Furthermore, in accordance with the theory of destructive creativity, bankruptcies enable innovation, removal of expansion barriers and effective exploitation of limited resources with benefits for owners and economy, within the realm of their function. Conversely, bankruptcies constitute a significant problem for a properly functioning national economy. In the context of globalization, centralization of capital markets and the emergence of multinational entities, a bankruptcy may engender global impact (Mączyńska, 2005).The financial problems of an enterprise frequently become problems of that enterprise's contracting parties. How intrinsic this relationship is depends on how closely the parties co-operate i.e. the closer the ties, the greater chance of the so called 'domino effect' wherein one bankruptcy initiates several others. With these dynamics in mind, it becomes clear that clearly defined circumstances and prognostication capabilities are essential. The use of financial indicators to appraise a company's condition has been under consideration since the early 1900's. The 1920's and 30's saw dynamic development of assessment methods for determining a company's financial standing; a result of that international market crisis. It was then that the first efforts were made to select those indicators which were relevant in forecasting commercial bankruptcy (Fitzpatrick, 1932). More intense study was initiated in the following years in establishing more complex tools and statistical methods. The first pioneer efforts of applying 'linear discriminant analysis' to assess a company's loss of liquidity were undertaken by E. I. Altman in 1968 (Altman, 1968). Seven years later, Altman, Haldeman and Narayanan (Altman, et al., 1977) took advantage of 'square discriminant analysis' to construct a prediction model. Martin (Martin, 1977) also presented studies taking advantage of logit models. The next adapted econometric method used for predicting bankruptcy risk was 'perceptron neural network' (Salchenberger, et al., 1992). Subsequent proposals involved more advanced methods for constructing models: 'probabilistic neural networks' (Yang, et al., 1999); 'radial basis function networks' (Charalambous, et al., 2000); 'logical neuron networks' (Tsakonas, et al., 2006); and 'non-linear discriminatory analysis' (Sori, et al., 2007). In addition to these models, researchers also took advantage of various techniques: 'one-dimension discriminant analysis' (Fitzpatrick, 1932); 'change in balance' analysis based on the theory of entropy (Merton, 1974); 'rough sets' (Dimitras, et al., 1999); the Wilcox model based on the 'gambler's ruin' theory (Wilcox, 1971); support vector model (Chen, 2011); option pricing model (Shumway, 2001); Merton's modified option model (Merton, 1974); fuzzy rules (Kumar \& Ravi, 2006); ant colony optimization theory (Khodadadi, et al., 2010) and hybrid methods - essentially combinations of various methods (Martin, et al., 2011). Model analysis based on the applied method indicates that methods do not significantly influence effective bankruptcy prediction of any given model where the results pertaining to various models oscillate - after work up - between 80 and $98 \%$, which should be recognized as satisfactory. The choice of which model to use is determined by ease of application. According to the literature models developed using the 
linear discriminant regression, logistic regression and neutral network give best application in market experience in a numerous group of companies which include (but not limited to) banks and financial institutions, rating institutions, investors, individuals managing enterprises, auditors, recipients and suppliers, local administration, factoring firms, company employees, government and underwriting agencies. Applying these imminent bankruptcy models, the mentioned entities anticipate gaining current status information on the condition of an enterprise and well-grounded indication for potential bankruptcy. At the same time they covet that the calculations are not overly complicated and the model is easily applied, which is in accordance with one of the fundamental precepts in applying models for assessing a company's condition. In response to the above, it was decided to take advantage of linear discriminant analysis, logistic regression and neutral network which are easily applied to market experience.

\section{Research Methodology}

The study encompassed 60 corporate entities in the whole sale food industry in the years 2009 to 2013, incorporated in the Polish Republic as limited liability companies, using their balances and profit and loss accounts. The sample selection was governed by purposive-random format. For the two phase study, sixty companies were selected wherein for the first phase, 20 'bankrupted in 2011' companies were randomly chosen. A further 20 were chosen having continuous activity; and for this determinant model construction phase, the data from 40 companies for 2009 and 2010 was examined; two full 'pre-bankruptcy' accounting periods were scrutinized. The commonalities of these 40 companies were utilized in examining the effectiveness of foreign and domestic determinant models. For the second phase of the study, another 20 companies, which were declared bankrupt in 2013, were randomly chosen. The same 'continual activity' group of the first phase was utilized but with the change that the data of both bankrupt and operating companies now pertained to 2011 and 2012. The collated data was used to verify the determinant model for a specific industry. The study took into account bankrupt companies which issued annual financial reports for at least 3 full accounting periods in Monitor Polski B (a Polish government daily regarding finances, reports, etc.) before petitioning a court to declare bankruptcy, and also were characterized by deficit spending (negative net worth) and financial losses. The contrasted side, those companies which were operational in 2013 since at least January 1, 2007, had comparable asset values to the bankrupt group with differentials no greater than 500,000. PLN. In 2011, Poland had 68 companies from whole sale food industry declare bankruptcy; solvent 392 companies. The established bankrupt group was then organized ascending, according to their National Court Register number, and twenty companies were chosen at random. Every third company was chosen beginning with the company in fourth position. The 'in operation' group was randomly established, also in that after being ordered by registration number, every nineteenth company was chosen beginning with the company in sixth position. In 2013, there were 46 companies in the wholesale food industry which 
declared bankruptcy; of these, once organized in ascending order, every second company was drawn beginning with the third position.

Upon choosing the companies, forty-two economic-financial indicators were determined whose choice was made based on their overall pervasion in this issue and usefulness in predicting bankruptcy or not. With the above two criteria in mind, the following indicators were chosen: X1 - Fixed Assets/Total Assets; X2 - Current Assets/Total Assets; X3 Current Assets/Current Liabilities; X4 - (Short-term Receivables + Short-term Investments)/Current Liabilities; X5- Sort-term Investments/Current Liabilities; X6 - Sales Revenue/Short-term Receivables; X7 - (Short-term Receivables/Sales Revenues) ${ }^{\star}$ 365; X8 - Sales Revenues/Current Liabilities; X9 - (Current Liabilities/Sales Revenues) ${ }^{\star} 365$; X10 - Sales Revenue/Inventory; X11 - (Inventory/Sales Revenue)*365; X12 - Average Collection Period + Inventory Turnover - Liability Turnover; X13 - Net Profits/Total Assets; X14 - Net Profits/Current Assets; X15 - Net Profits/Fixed Assets; X16 - Net Profit/Sales Revenue; X17 - Total Assets/Equity Capital; X18 - Total Liabilities/Equity Capital; X19 - Equity Capital/Fixed Assets; X20 - Sales Revenue/Total Assets; X21 Sales Revenue/Fixed Assets; X22 - General Operating Costs/Gross Revenue; X23 Equity Capital/Sales Revenue

In addition to the above listed indicators, the difference of the value in the average of the wholesale food industry regarding a specific indicator and that of a given company was taken into account. An indicator with the sub-script ' $\mathrm{B}$ ' denotes an industry average as determined by the Central Statistical Office of Poland, and the sub-script ' $P$ ' denotes a particular value for a participating company. The following indicators were utilized for the study: X24 = X22B - X22P; X25 = X16B - X16P; X26 = X13B - X13P; X27 = X15B $\mathrm{X} 15 \mathrm{P} ; \mathrm{X} 28=\mathrm{X} 14 \mathrm{~B}-\mathrm{X} 14 \mathrm{P} ; \mathrm{X} 29=\mathrm{X} 3 \mathrm{~B}-\mathrm{X} 3 \mathrm{P} ; \mathrm{X} 30=\mathrm{X} 4 \mathrm{~B}-\mathrm{X} 4 \mathrm{P} ; \mathrm{X} 31=\mathrm{X} 5 \mathrm{~B}-\mathrm{X} 5 \mathrm{P}$.

Fundamental categories of economic dynamics were also taken into account to establish whether directional changes indicated imminent bankruptcy. In this category the following indices were chosen: X32 = (Sales Revenues)t/(Sales Revenues) $(\mathrm{t}-1) ; \mathrm{X} 33=$ (Total Assets)t/(Total Assets)(t-1); X34 = (Current Assets)t/( Current Assets)(t-1); X35 = (Fixed Assets)t/( Fixed Assets)(t-1), X36 = (Equity Capital)t/( Equity Capital)(t-1); X37 = (Outside Capital)t/( Outside Capital)(t-1); X38 = (Current Liabilities)t/( Current Liabilities)(t-1); X39 $=($ Results of Operating Activities $) \mathrm{t} /($ Results of Operating Activities $)(\mathrm{t}-1) ; \mathrm{X} 40=($ Net Financial Results)t/(Net Financial Results)( $t-1)$. Where ' $t$ ' indicates the previous full accounting year preceding bankruptcy; and ' $t-1$ ' indicates the second year preceding bankruptcy. Taking into account the differences between analyzed entities resulting from attributes of their industry, two essential indices - of the past and present - were chosen to reflect changes as determined by the Central Statistical Office: price change of food (previous year $=100$ ); wholesale food growth rate in value terms (previous year $=100$ ). These above two industry related indices were utilized to demonstrate the rate of change in accounts receivable, indicated by the sub-script 'WS' for wholesale food. Further in the 
study, the following indices will be employed: X41WS $=(($ Sales Revenue)t/( Sales Revenue)(t-1))/Price Change in of Food, X42WS $=$ ((Sales Revenue)t/( Sales Revenue)(t-1))/ Wholesale food growth rate in value terms.

In the first phase of the study whose purpose was to construct a model which would enable anticipation of imminent bankruptcy in the industry, the selected companies were divided into two groups. The first group included bankrupted companies; the second, companies which had had continuous operation. On the basis of data gathered from financial statements and figures from the Central Statistical Office, calculated were financial-economic indicators which were then utilized to assess current foreign and domestic determinant models, as well as constructing an authored industry model, and, in the second phase of the study, verifying the new constructed model for reliability. The study took advantage of econometric methods for processing data which allowed the formulation of an industry model making it possible to forecast bankruptcy risk for companies in the wholesale food industry. The developed industry model was constructed through the use of discriminant analysis used for resolving issues related to classifying collections of differentiated characteristics. In addition, for comparison, bankruptcy prediction model were constructed using the method of logistic regression and artificial neural networks. Discriminant analysis depends on estimating linear discriminant function figures allowing for the differentiation of studied multi-dimensional collections (Lachenbruch, 1975), through designating linear combined qualities which differentiate two or more class objectives. Linear Discriminant Function appears as such (Kolonko, 1980):

$Z(x)=a_{1} X_{1}+a_{2} X_{2}+\ldots+a_{k} X_{k}$

where:

$a_{1}, a_{2} \ldots, a_{k}-$ discriminant coefficients,

$X_{1}, X_{2}, \ldots, X_{k}$ - variable diagnostic value.

Based on information from observations of actual affiliation, the procedural scheme is determined which will in future allow assigning observations outside defined parameters to various classes while minimizing errors (Kendall \& Buckland, 1975).

On the basis of works on the subject, and on the collated data of the studied companies and industry, several economic-financial indicators were chosen which could potentially become the explanatory variables. In the case where the exogenous variable for indicating bankruptcy probability - financially solvent companies were assigned a value of 1; where the company should be declared 'imminently insolvent', a value of 0 (zero). During further efforts, from among the exogenous variables, attention was directed to the requirement that variables correlate strongly to the 'bankruptcy indicator', but be independent of each other (Borkowski, et al., 2003) (Mączyńska \& Zawadzki, 2006). To 
monitor this, 'collinear correlation' analysis was utilized (Grabiński, et al., 1982) (Kufel, 2007). In the second phase of constructing the model, estimations were carried out regarding structural parameters of the linear discriminant function model by applying the classic method of 'least square' (Witkowska, 2006), which allows for estimating structural parameters of the described linear model by the following formula:

$y_{i}=\beta_{0}+\beta_{1} x_{1 i}+\beta_{2} x_{2 i}+\ldots+\beta_{k} x_{j i}+\varepsilon_{i}$

where:

$i=1,2, \ldots, n$,

$y_{i}-\mathrm{i}$ being the observation event number regarding a exogenous variable,

$x_{j i}-\mathrm{i}$ being the observation, $\mathrm{j}$ being the variable,

$\varepsilon_{i}$ - random element.

Parameter estimation of a model with numerous explanatory variables by the least square method resulted in parameter values ${ }^{\beta_{j}}$, which are minimalized by the following equation:

$S\left(b_{0}, b_{1}, b_{2}, \ldots, b_{k}\right)=\sum_{i=1}^{n}\left(y_{i}-b_{0}-b_{1} x_{1 i}-b_{2} x_{2 i}-\ldots-b_{k} x_{k i}\right)^{2}$

The linear discriminant analysis requires the independent variables included in the model to be normally distributed, and the variance-covariance matrices to be equivalent across the failing and the non-failing groups. Both these conditions are often violated when the linear discriminant analysis is employed in the development of default prediction models. Therefore, many studies favor logistic regression over linear discriminant analysis thereby implying that it is the best parametric technique.

The logistic regression model assumes that the probability of a dichotomous outcome is related to a set of potential predictor variables in the form:

$$
\log \left[\frac{p}{1-p}\right]=\beta_{0}+\beta_{1} x_{1}+\beta_{2} x_{2}+\ldots+\beta_{n} x_{n}
$$

where $p$ is the probability of the outcome of interest, b0 is the intercept term, and $b i(i=1$, $\ldots, n)$ represents the $b$ coefficient associated with the corresponding explanatory variable $x i(i=1, \ldots, n)$ (Witkowska, 2006). The dependent variable is the logarithm of the odds, which is the logarithm of the ratio of the two probabilities of the outcome of interest. These variables are usually selected for inclusion by using some form of backward or forward stepwise regression technique even though these selection techniques may be prone to problems. The maximization of the likelihood function is commonly applied as 
the convergent criterion to estimate the coefficients of corresponding parameters when the logistic regression models are utilized.

Artificial neural network is a type of information process pattern that inspired from inherent or natural neural systems. Artificial neural networks are dynamic systems that can transfer hidden rules and knowledge of data into network structure through experimental data processing. So, this is called intelligent system. Neural networks are composed of a series of layers that include simple parts of processor called neuron and they can act in parallel. Each input layer is related to one or more middle layer and also middle layers are connected to output layer. Since many factors like hidden layers, the number of hidden layers neurons, data normalization and learning algorithm, have an effect on neural networks function, so, the best architecture of neural network will be obtained through experiment and try and error. Error Back Propagation network that is a type of feed forward network has been used. Transformation function used in this study, is a sigmoid function that its formula is quall to: $f(n e t)=(1+e-n e t)-1$. Net means: the total weight of input variable from previous layer. By this function, the output variable amount will be between zero and one. Performance function for network raining is considered as the mean sum of squared errors.

In the case of determinant analysis, three types of effectiveness and incorrect classification. In the case of 'model effectiveness', we see:

Effectiveness - First Degree (SP2) establishes the percent of accurately classified companies at risk of bankruptcy, determined according to the formula:

$S P_{1}=\frac{P_{1}}{P_{1}+N P_{1}} \cdot 100 \%$

Effectiveness - Second Degree (SP2) establishes what percent of all analyzed companies as not-at-risk of bankruptcy were identified accurately, based on the formula:

$$
S P_{2}=\frac{P_{2}}{P_{2}+N P_{2}} \cdot 100
$$

Overall Effectiveness (SP0) - demonstrates what percent of all companies analyzed were classified correctly by the model. The formula enabling effectiveness determination is

$S P_{0}=\frac{P_{1}+P_{2}}{P_{1}+N P_{1}+P_{2}+N P_{2}} \cdot 100 \%$

Where the formulae use these symbols: P1 - anticipated number of bankrupted companies classified as 'at risk', P2 - anticipated number of operational companies classified as 'not at risk', NP1 - number of operational companies classified as 'at risk', NP2 - number of bankrupted companies classified as 'not at risk'. 
Determining the validity of the model and its forecast degree of error, in the test group and the group used for formulating the model, enabled model assessment with regard to practical applicability.

\section{Results}

Determining key indicators defining bankruptcy risk was undertaken utilizing coefficient correlation analysis between the exogenous variable and the explanatory (endogenous) variables, and between all the explanatory variables. In order to construct the discriminant function allowing for accurate indication of bankruptcy risk, or lack of, backward stepwise regression was applied. After estimating the parameters of the regression functions, the functions were also assessed statistically and substantively for prognostication of bankruptcy risk. Three fundamental criteria were taken into account while generating the model. First, the model must be sufficiently efficient i.e. the results of the parent sample should accurately assess risk at higher than $80 \%$ with one year advance warning. Second, the model should take into account the fact that the financial data pertains to enterprises having their headquarters in Poland; and third, the model should be easy to apply.

Taking advantage of the indicator scheme for the model, key economic/financial indicators were chosen which could potentially be the bankruptcy risk predictors. In accordance with correlation coefficient analysis, the first step required working up a correlation matrix between the exogenous variable and all the economic/financial indicators; then a similar matrix between those 42 economic/financial variables. Next in order was the critical correlation coefficient determination, which was the reference point for the elimination of one-of-two highly correlated explanatory variables. In the case of the studied commercial sector, the critical correlation coefficient value was: $r^{*}=0.3120$

Generally, the weaker correlated variable - to the exogenous variable - was discarded. Generated next was the correlation matrix with a lower number of potential explanatory variables. This procedure was repeated until a set of explanatory variables were established which were strongly correlated with the exogenous variable but weakly with each other. Applying the correlation coefficient analysis methods, established was that 10 out of the original explanatory variables were statistically significant: X17; X19; X23; X30; X31; X32; X36; X38; X39

The next phase estimated the parameters of the discriminant function utilizing the classic methods of least squares. Subsequent phases included the backward stepwise regression methods which eliminated specific variables with the help of Student's t-test. As a consequence of these procedures, the following configuration of the discriminant function was reached. The assessment parameters of the discriminant function - ZFDWF ZFDWF=1,16823X23-0,011048X30 + 0,116909X38 
where:

X23 - Equity Capital/Sales Revenue

$\mathrm{X} 30=\mathrm{X} 4 \mathrm{~B}-\mathrm{X} 4 \mathrm{P}$

X38 $=($ Current Liabilities $) \mathrm{t} /($ Current Liabilities $)(\mathrm{t}-1)$.

For the model ZDFWF was considered boundary point at level of zero.

The best neural network, which was using available independent variables proved perceptron network shown in Figure 1, with one hidden layer containing four neurons.

\section{Figure 1: Perceptron network neutral network}

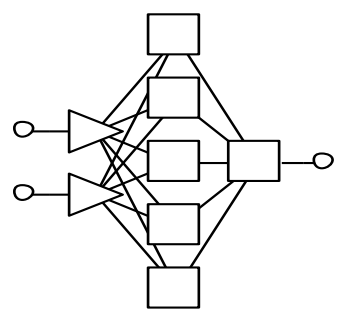

Source: author's own figures

At the output of one neuron is, while the network includes two entrances. An important advantage of neural networks is the ability to selecting the relevant independent variables. Irrelevant variables are automatically eliminated by the network. For major networks have been created only two variables. The first is a pointer X23 - Equity Capital/Sales Revenue and X38 = (Current Liabilities)t/(Current Liabilities)(t-1).

In the case of logistic regression model estimated function adopted consisted of four variables and constant, and the regression coefficients for the variables are described in the following equation:

ZRLWF=1,236+1,20X23+0,26X30+0,10X32-0,32X38

where:

X23 - Equity Capital/Sales Revenue

$\mathrm{X} 30=\mathrm{X} 4 \mathrm{~B}-\mathrm{X} 4 \mathrm{P}$

X32 $=($ Sales Revenues) $\mathrm{t} /($ Sales Revenues) $(\mathrm{t}-1)$,

X38 $=($ Current Liabilities $) \mathrm{t} /($ Current Liabilities $)(\mathrm{t}-1)$.

For functions ZRLWF was considered boundary point at level of 0.5 . 
In order to corroborate the accuracy or performance of the model, it was checked against a group of bankrupt and solvent companies on the basis of which it was constructed and entities outside this control group where it was known whether they were bankrupt or solvent.

On the basis of the determined differential, and the constructed model, initially the performance assessment was applied to the companies used for the model construction.

The analysis showed that, of the constructed model was the best discriminatory model ZFDWF, which was characterized by the highest level of efficiency. Detailed information is provided in Table 1.

\section{Table No. 1: Accuracy of Constructed Models in Forecasting Bankruptcy for Wholesale food Companies (\%)}

\section{Model Effectiveness}

\begin{tabular}{|c|c|c|c|c|c|c|c|c|c|}
\hline \multirow[t]{2}{*}{ Group } & \multicolumn{3}{|c|}{$\begin{array}{l}\text { Linear discriminant } \\
\text { regression }\end{array}$} & \multicolumn{3}{|c|}{ Neutral network } & \multicolumn{3}{|c|}{ Logistic regression } \\
\hline & $\mathrm{SP}_{1}$ & $\mathrm{SP}_{2}$ & $\mathrm{SP}_{0}$ & $\mathrm{SP}_{1}$ & $\mathrm{SP}_{2}$ & $\mathrm{SP}_{0}$ & $\mathrm{SP}_{1}$ & $\mathrm{SP}_{2}$ & $\mathrm{SP}_{0}$ \\
\hline $\begin{array}{l}\text { Learning } \\
\text { sample }\end{array}$ & 90 & 95 & 92 & 90 & 90 & 90 & 80 & 80 & 80 \\
\hline $\begin{array}{l}\text { Testing } \\
\text { sample }\end{array}$ & 85 & 90 & 87 & 80 & 75 & 77 & 60 & 80 & 70 \\
\hline
\end{tabular}

Source: author's own figures

It should be noted that the second best performance was a model of neutral network but the worst result had logistic regression model.

First degree (SP1) performance for the model ZFDWF was 90\%, which means that 18 out of 20 companies were rated as bankrupt and were rated correctly. Second degree (SP2) performance, properly rating companies as solvent by the ZFDWF model, was $95 \%$. Overall (SP0) performance, accurate rating of all analyzed companies by the model was $92,5 \%$. This is a moderately satisfactory result and gives opportunity for the model's effective application in business practice to establish bankruptcy risk for companies in the wholesale food sector. Effectiveness verification of the ZFDTRA model on the test group indicated that overall bankruptcy forecast performance in the case of wholesale food sector was $87.5 \%$. The components of this assessment are the high accuracy of 
identifying solvent companies (85\%), and the somewhat lower performance in identifying bankrupt companies (90\%).

\section{Discussion and Conclusions}

The maintenance of appropriate rational and stable liquidity which increases profitability and value of a company is a daunting task. Conversely, high unemployment and the variable co-operation between corporations and banks in regard to financial investment and employment, requires the improvement of tools which would allow banks to relatively quickly and accurately assess commercial enterprise on the verge of bankruptcy. In this contemporary economy, it is essential to maintain growth, reduce unemployment and raise public revenues; therefore the financial success of corporate investments, in cooperation with commercial banks, lies in the interest of both sides, as well in the interest of national and European economies. A condition for these benefits is reducing the credit risk for banks based on improved financial tools which differentiate endangered from stable commercial entities. This demand justifies the improvement of, among others, differential methods for assessing bankruptcy risk of individual commercial entities. This knowledge alone is a key in the area of co-operation between a company and its bank where delayed recognition of risk may engender loss of borrowed money. A separate consideration is the issue whether current Polish and foreign differentiation models are sufficient and can they be applied to the wholesale food industry without restriction. An intrinsic question of this issue is will a model designed to ascertain potential bankruptcy for this specific enterprise significantly reduce the risk of faulty bankruptcy assessment as compared to general contemporary models. Taking the above considerations into account, the authors subjectively determined that the questions are significant enough to undertake an initial investigation of this issue.

Analyzing the results of research it should be paid attention on the indicator X30 representing the difference between the quick liquidity indicator for the industry and for the company. The negative regression coefficient value of this variable indicates that more favorable to an assessment of financial standing of the company is maintaining quick liquidity ratio by the company above the industry average. Achieving good results in the wholesale food industry is closely linked with maintaining higher level of liquidity which allows for efficient regulation of company's liabilities. It may be important that the company engaged in the wholesale of food should primarily seek to increase their market and current receivables. This variable indirectly points to the importance of proper stock management which in the case of wholesale of food industry is especially important as the state of stocks in wholesale companies is mostly significant.

Indicators X23 and X38 in the estimated discriminant function for the wholesale food industry should be considered as stimulants because of their higher level have positive influence on the assessment of the condition of the company using the model. Indicator $\mathrm{X} 23$, the ratio of own equity and the revenue from sale, points to the need for a significant 
level of equity in comparison to the volume of revenue from sales. This means that revenue growth should translate into at least proportionately increase of own equity which may be the result of increased of net profit. Moreover this shows that wholesale food sector is very difficult and requires of constant investments. It should be noted that the increase of this indicator has positive influence on the reducing risk of bankruptcy of companies from wholesale food sector.

Indicator X38 which expresses the dynamics of company's short term liabilities is indicating a positive aspect of reasonable indebtedness of companies form wholesale food sector probably through trade credits, which is closely related to the functioning of this industry. In the case of companies involved in such activities it is economically justified since most good delivered to the warehouse is characterized by relatively long period of payment for the goods. Therefore the increase in short-term debts testifies to the potential increase of supply and sales opportunities.

Perhaps the key is that the managers of these companies should provide a considerably shorter payment period for goods sold than purchased, as well as quick stocks rotation.

Based on the results of other research and this analysis, it should be noted that as a result of continued market changes over the years the comprehensive applicability deteriorated for almost all contemporary discriminant models; therefore it can be assumed that this constructed model for companies in the wholesale food sector will require modification in the near future in order to maintain satisfactory forecast performance.

\section{References}

ALTMAN, E. I., 1968. Financial Ratios, Discriminate analysis and the prediction of corporate bankruptcy. Journal of Finance, 4(23).

ALTMAN, E. I., HALDEMAN, R. G. \& NARAYANAN, P., 1977. ZETA ANALYSIS, a new model to identify bankruptcy risk of corporations. Journal of Banking \& Finance, Volume 1. https://doi.org/10.1016/0378-4266(77)90017-6

BEBA, P., POCZTA, W., 2014. Rozwój i rola polskiego przemysłu spożywczego w warunkach akcesji do Unii Europejskiej. Polityki Europejskie, Finanse i Marketing. Vol. 11. No. 60.

BORKOWSKI, B., DUDEK, H. I SZCZĘSNY, W., 2003. Ekonometria. Wybrane zagadnienia. Warszawa: PWN.

CHARALAMBOUS, C., CHARITOU, A. I KAOUROU, F., 2000. Comparative analysis of artificial neural network models: Application in bankruptcy prediction. Annals of Operations Research, Tom 99.

CHEN, S., 2011. Modeling default risk with support vector machines. Journal of Quantitative Finance, Issue 11(1), pp. 135-154. https://doi.org/10.1080/14697680903410015 
DIMITRAS, A., SLOWINSKI, R., SUSMAGA, R. I ZOPOUNIDIS, C., 1999. Business Failure Prediction Using Pough Sets,. European Journal of Operational Research, Tom 114, pp. 263-280.

FITZPATRICK, P. J., 1932. A comparison of ratios of successful industrial enterprises with those of failed firms,. Certified Public Accountant, Volume 12, pp. 598-605.

GRABIŃSKI, T., S., W. I ZELIAŚ, A., 1982. Metody doboru zmiennych w modelach ekonometrycznych. Warszawa: PWN.

KENDALL, M. G. I BUCKLAND, W. R., 1975. A Dictionary of Statistical Terms,. London: Longman for the International Statistical Institute.

KHODADADI, V., A., Z. \& NOURI, M., 2010. Application of Ants Colony System for Bankruptcy Prediction of Companies listed in Teheran Stock Exchange. Business Intelligence Journal, 3(2), pp. 89-100.

KOLONKO, J., 1980. Analiza dyskryminacyjna i jej zastosowanie w ekonomii. Warszawa: PWN.

KUFEL, T., 2007. Ekonometria. Rozwiązywanie problemów z wykorzystaniem programu GRETL. Warszawa: PWN.

KUMAR, P. R. I RAVI, V., 2006. Bankruptcy Prediction in Banks by Fuzzy Rule Based Classifier. Transactions on Fuzzy System..

LACHENBRUCH, P. A., 1975. Discriminant analysis. New York: Hafner.

MĄCZYŃSKA, E., 2005. Ekonomiczne aspekty upadłości przedsiębiorstw w Polsce. Warszawa: Wydawnictwo SGH.

MĄCZYŃSKA, E. \& ZAWADZKI, M., 2006. Dyskryminacyjne modele predykcji upadłości przedsiębiorstw,. Ekonomista, Tom 2, pp. 205-217.

MARTIN, A. ET AL., 2011. A Hybrid Model for Bankruptcy Prediction Using Genetic Algorithm, Fuzzy Cmeans and Marsi. International Journal on Soft Computing, February.2(1).

MARTIN, D., 1977. Early warning of bank failure: A logit regression approach. Journal of Banking \& Finance, Volume 1. https://doi.org/10.1016/0378-4266(77)90022-X

MERTON, R. C., 1974. On the Pricing of Corporate Debt: The Risk Structure of Interest Rates. Journal of Finance, 29(2), pp. 449-470.

SALCHENBERGER, L. M., CINAR, E. M. I LASH, N. A., 1992. Neutral networks: A new tool for predicting thrift failures. Decisions Science, Tom 23.

SHUMWAY, T., 2001. Forecasting bankruptcy more accurately: a simple hazard model. Journal of Business, Tom 74, pp. 101-124.

SORI, Z., HAMID, M. A. A. I NASSIR, A., 2007. Forecasting Financial Problems in Emerging Capital Markets. Social Sciences Research Network. 
TSAKONAS, A., DOUNIAS, G., DOUMPOS, M. \& ZOPOUNIDIS, C., 2006. Bankruptcy prediction with neural logic networks by means of grammar-guided genetic programming. Experts Systems with Applications, Volume 30.

WILCOX, A., 1971. A Simple Theory of Financial Ratios as Predictors of Failure. Journal of Accounting Research, pp. 389-396. https://doi.org/10.2307/2489944

WITKOWSKA, D., 2006. Podstawy ekonometrii i teorii prognozowania. Podręcznik z przykładami $i$ zadaniami. Kraków: Wydawnictwo Oficyna Ekonomiczna.

YANG, Z. R., PLATT, M. B. I PLATT, H. D., 1999. Probabilistic neutral Networks in Bankruptcy Prediction,. Journal of Business Research, Tom 44. 